\title{
Sewage monitoring is the UK's next defence against covid-19
}

chrisbaraniuk@gmail.com

Cite this as: BMJ2020;370:m2599 http://dx.doi.org/10.1136/bmj.m2599 Published: 15 July 2020

\section{Researchers have pioneered wastewater analysis and are now contributing to a nationwide programme, reports Chris Baraniuk}

\section{Chris Baraniuk}

For the past few months, scientists in the UK have been quietly poring over samples of British faeces. Researchers at a handful of universities around the country have been conducting pilot programmes to detect RNA from the SARS-CoV-2 virus deposited in sewage, which ends up at wastewater treatment plants.

"We estimate if there's one person infected in a population of 10 ooo, we can pick it up-it's that sensitive," says Davey Jones, professor of soil and environmental science at Bangor University.

Every week since March, Jones's team has been analysing wastewater-which flows into sewers from bathrooms, kitchens, and public drains-from cities including Cardiff, Liverpool, and Manchester. He says that the volume of viral RNA present in the samples noticeably "plummeted" after the UK went into lockdown in late March, an apparent indicator of the falling number of cases that resulted from social distancing.

Now, he's signed a contract to expand sampling to 20 wastewater treatment plants around Wales. It's a "daughter project," he says, of a UK-wide sewage surveillance programme to monitor the presence of the virus in wastewater, which was announced on 12 June by the Department for Environment, Food, and Rural Affairs (DEFRA).

Details of other projects in the scheme haven't yet been made public, but The BMJ understands that, in total during the initial phase, around 50 wastewater treatment sites around the UK will be sampled a few times a week. Researchers are sampling a few sites already, with the rest to follow by the end of the summer. Other countries, including Australia and Spain, had previously committed to similar monitoring programmes.

\section{Early warning system}

Infected people sometimes naturally shed virus material in their faeces within a couple of days of symptoms appearing. This means that regular checks of sewage could theoretically identify the presence of the virus before an infected person gets the results of a swab test. To detect viral material, a wastewater sample must be brought to a laboratory where it is purified and filtered before the RNA is extracted. This is then processed by quantitative polymerase chain reaction-the same sort of analysis used to detect viral RNA in swab tests from patients.

This approach is not $100 \%$ specific, meaning that there are likely to be occasional false positives. Scientists can, however, control for possible contamination of samples and eliminate poor results.
RNA fragments in sewage are not likely to be infectious. However, finding them in wastewater reveals that there are infected people in the community.

“This is kind of an early warning system," says Barbara Kasprzyk-Hordern, a professor in chemistry at the University of Bath, who thinks such monitoring could help local authorities control local hotspots of the virus that may emerge in the coming months. Some countries, including Israel, ${ }^{2}$ have used sewage monitoring to detect outbreaks of polio in the past, so the idea is not without precedent.

Some scientists say it may even be possible to roughly quantify how many infected people there are in a given town based on the amount of viral RNA that turns up in that town's wastewater.

As with other aspects of the covid-19 response in the UK, efforts to monitor sewage were not initiated by the government but rather proposed and prototyped by academic researchers.

"I got in touch with Scottish Water and asked if anybody was looking at the detection of coronavirus in wastewater. They said, 'No, why don't you crack on with it,"' says Alex Corbishley, lecturer in farm animal practice at the University of Edinburgh. That was more than three months ago. He's since obtained multiple samples from six wastewater plants in Scotland and successfully detected SARS-CoV-2 in them.

\section{Detective work}

There are, however, challenges involved in wastewater monitoring. The proportion of the virus present in wastewater can change depending on the amount of rainwater entering the sewage system, for instance. Or, temperature and other factors could alter the amount of viral material that survives in one city's sewers compared with another's. Wastewater from areas with more hospitals or care homes might contain greater amounts of viral RNA. Plus, things can change over time. As people move out of lockdown, the use of residential bathrooms will likely fall, again altering what turns up at the treatment plant.

In order to be able to take samples from a wastewater facility and make a reliable estimate as to how many people are infected in that area, all of the above factors need to be taken into account, says Andrew Singer, senior scientist at the UK Centre for Ecology and Hydrology.

Researchers also need to control for the time of day at which a sample was taken, since, as with the electricity grid, demand on sewers varies between 
morning and night. Current methods of purification mean significant proportions of viral material-up to $80 \%$-can be lost from samples so this needs to be considered too, says Singer. Corbishley adds that he has tried to solve this by inserting a known quantity of pig virus into his samples to see how much is left by the time the specimen is purified and ready for analysis.

“It's like detective work," says Singer.

\section{Waiting to start}

Another researcher who has been gathering samples and conducting early experiments in the UK is David Graham, professor of ecosystems engineering at Newcastle University. He says that only taking samples from wastewater treatment plants limits the information scientists can gather about what parts of a city are worst affected by covid-19.

"Say you've got the city of Newcastle, which has about 400 ooo people, and there's two waste treatment plants-that doesn't tell you very much about the epidemiology of the disease within a city of that size," he explains.

Since March, he and colleagues have been gathering samples from localised points instead: pump stations and junctions scattered across Newcastle's sewer system. He says that they've gathered between 250 and 300 vials of wastewater and are now starting to analyse the first of these.

Singer adds that analysis in the UK will be propped up by a research programme to improve the overall sensitivity of wastewater analysis. His proposal for this work received $€ 1 \mathrm{~m}(€ 1.1 \mathrm{~m} ; \$ 1.2 \mathrm{~m})$ in funding in early July.

However, although DEFRA has committed to the wider nationwide sewage surveillance scheme, there are few public details about it, notes Singer. The BMJ asked DEFRA if it could clarify the scope of the programme: a spokesperson declined to comment but said more information would follow "in the coming weeks."

Commissioned, not externally peer reviewed

1 Parasa S, Desai M, Thoguluva Chandrasekar V, et al. Prevalence of gastrointestinal symptoms and fecal viral shedding in patients with coronavirus disease 2019: a systematic review and meta-analysis. JAMA Netw Open 2020;3:

doi: 10.1001/jamanetworkopen.2020.11335 pmid: 32525549

2 Eisenberg M, Brouwer A, Eisenberg J. Sewage surveillance is the next frontier in the fight against polio. 19 October 2018. https://theconversation.com/sewage-surveillance-is-the-next-frontierin-the-fight-against-polio-105012. 